\title{
Multi-Function Gas Fired Heat Pump
}

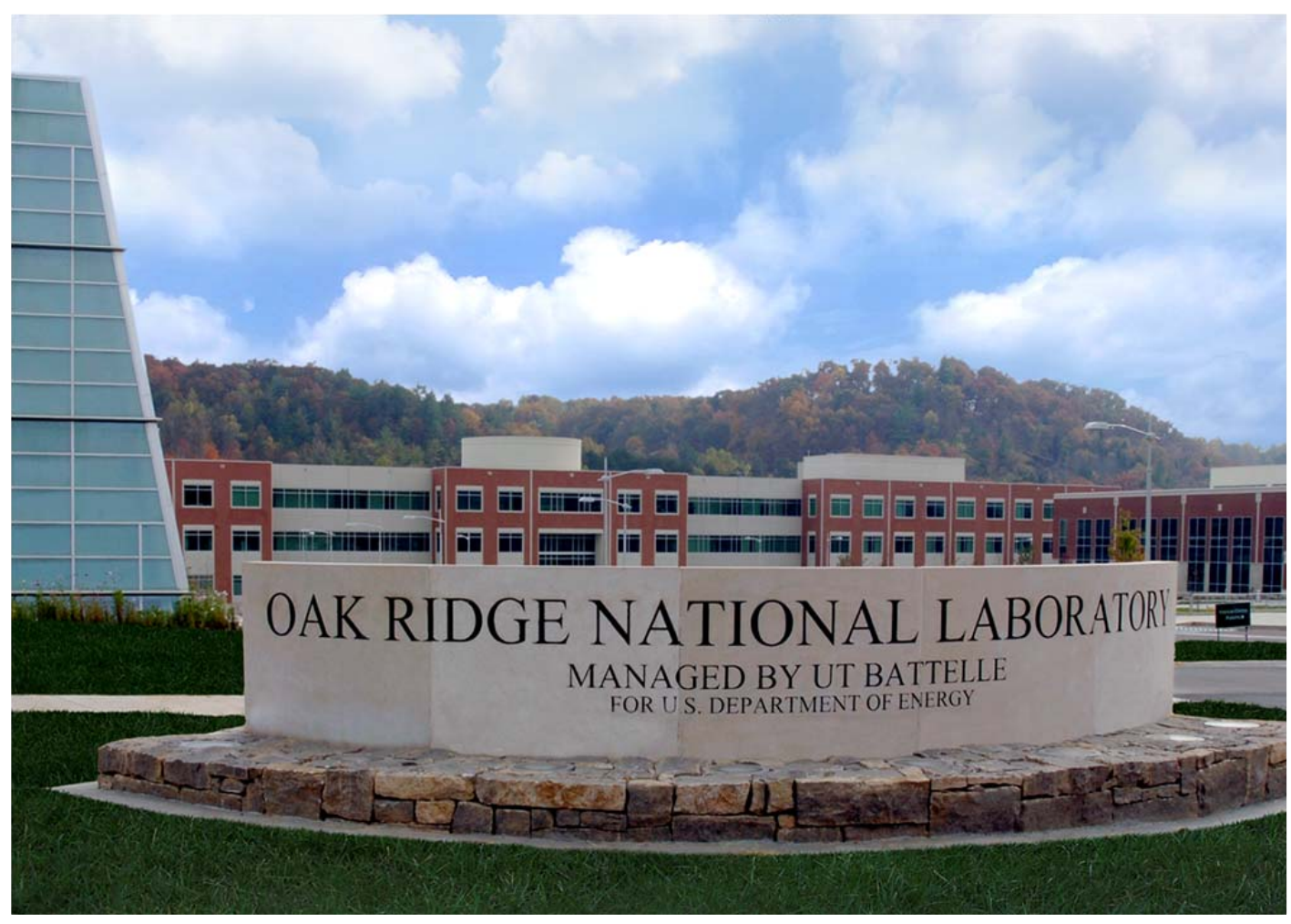

CRADA FINAL REPORT

NFE-10-02997

Approved for public release. Distribution is unlimited.
Ayyoub M. Momen Ahmad Abu-Heiba Edward Vineyard

Date: $11 / 30 / 2015$ 


\section{DOCUMENT AVAILABILITY}

Reports produced after January 1, 1996, are generally available free via US Department of Energy (DOE) SciTech Connect.

Website http://www.osti.gov/scitech/

Reports produced before January 1, 1996, may be purchased by members of the public from the following source:

National Technical Information Service

5285 Port Royal Road

Springfield, VA 22161

Telephone 703-605-6000 (1-800-553-6847)

TDD 703-487-4639

Fax 703-605-6900

E-mail info@ntis.gov

Website http://www.ntis.gov/help/ordermethods.aspx

Reports are available to DOE employees, DOE contractors, Energy Technology Data Exchange representatives, and International Nuclear Information System representatives from the following source:

Office of Scientific and Technical Information

PO Box 62

Oak Ridge, TN 37831

Telephone 865-576-8401

Fax 865-576-5728

E-mail reports@osti.gov

Website http://www.osti.gov/contact.html

This report was prepared as an account of work sponsored by an agency of the United States Government. Neither the United States Government nor any agency thereof, nor any of their employees, makes any warranty, express or implied, or assumes any legal liability or responsibility for the accuracy, completeness, or usefulness of any information, apparatus, product, or process disclosed, or represents that its use would not infringe privately owned rights. Reference herein to any specific commercial product, process, or service by trade name, trademark, manufacturer, or otherwise, does not necessarily constitute or imply its endorsement, recommendation, or favoring by the United States Government or any agency thereof. The views and opinions of authors expressed herein do not necessarily state or reflect those of the United States Government or any agency thereof. 
Energy and Environmental Science Division

\title{
Multi-Function Gas Fired Heat Pump
}

\author{
Ayyoub M. Momen \\ Ahmad Abu-Heiba \\ Edward Vineyard
}

Date Published: 11/30/2015

\author{
Prepared by \\ OAK RIDGE NATIONAL LABORATORY \\ Oak Ridge, Tennessee 37831-6283 \\ managed by \\ UT-BATTELLE, LLC \\ for the \\ US DEPARTMENT OF ENERGY \\ under contract DE-AC05-00OR22725
}

Approved For Public Release 



\begin{abstract}
The aim of this project was to design a residential fuel fired heat pump and further improve efficiency in collaboration with an industry partner - Southwest Gas, the developer of the Nextaire commercial rooftop fuel-fired heat pump. Work started in late 2010. After extensive search for suitable engines, one manufactured by Marathon was selected. Several prototypes were designed and built over the following four years. Design changes were focused on lowering the cost of components and the cost of manufacturing. The design evolved to a final one that yielded the lowest cost. The final design also incorporates noise and vibration reduction measures that were verified to be effective through a customer survey. ETL certification is currently (as of November 2015) underway. Southwest Gas is currently in talks with GTI to reach an agreement through which GTI will assess the commercial viability and potential of the heat pump. Southwest Gas is searching for investors to manufacture the heat pump and introduce it to the market.
\end{abstract}

\title{
STATEMENT OF OBJECTIVES
}

The purpose of this Cooperative Research and Development agreement (CRADA) between UTBattelle, LLC (the "Contractor") and Southwest Gas Corporation (SWG, herein "Participant") was to conduct research and development to evaluate the commercial viability of a residential fuel fired multifunction heat pump.

Under this CRADA project the following tasks were undertaken: 1) evaluate design options for a fuel fired multifunction heat pump (FFMHP), which will include space conditioning and water heating functions, suitable for the current, U.S. residential housing market; 2) produce a breadboard system for lab testing, and accomplish said testing; 3) develop a control strategy for optimal control of the FFMHP; 4) develop a full scale prototype for testing, and accomplish said testing; and 5) fabricate field test units, develop a field test plan, and accomplish said testing according to the plan. Thus, the project will accomplish the necessary development to evaluate a commercial product offering by the Participant for a residential FFMHP.

\section{BENEFITS TO THE FUNDING DOE OFFICE'S MISSION}

Gas engine driven heat pumps save primary energy by reducing the electric power losses associated with the thermal efficiency of electricity generation plants and transmission of electricity from generation sources to end-use sites. This in turn also reduces the greenhouse gases emissions. Gas heat pumps also reduce electric demand $(\mathrm{kW})$ by $80 \%$.

\section{TECHNICAL DISCUSSION OF WORK PERFORMED BY ALL PARTIES}

In November 2010, a design meeting was held in Las Vegas to discuss engine selection and unit output of the FFMHP. Jointly ORNL and SWG developed the heating, cooling and water heating capacity goals and specifications for the breadboard system design based on a fully integrated unit that provides space heating, space cooling and water heating. The design of the FFMHP was determined to be of a "split" system type with the engine and outdoor (condensing) section located outside the residence, and 
the indoor section (the indoor fan and evaporator coil) installed inside the structure. The design team identified an internal combustion (IC) engine suitable for the FFMHP application - see Figure 1. The IC engine is a single cylinder, 4-stroke reciprocating engine of $270 \mathrm{cc}$ displacement. It develops 7.5 horsepower while operating between $1,700 \mathrm{rpm}$ and 3,400 rpm, providing the variable speed that the technology uses. Its fuel consumption ranges from $31 \mathrm{cu}$. ft./min. to $67 \mathrm{cu}$. $\mathrm{ft} . / \mathrm{min}$. The engine is designed to run for 4,000 continuous hours before maintenance with 40,000 hour life expectancy before a major overhaul. This engine also meets current EPA emissions regulations.

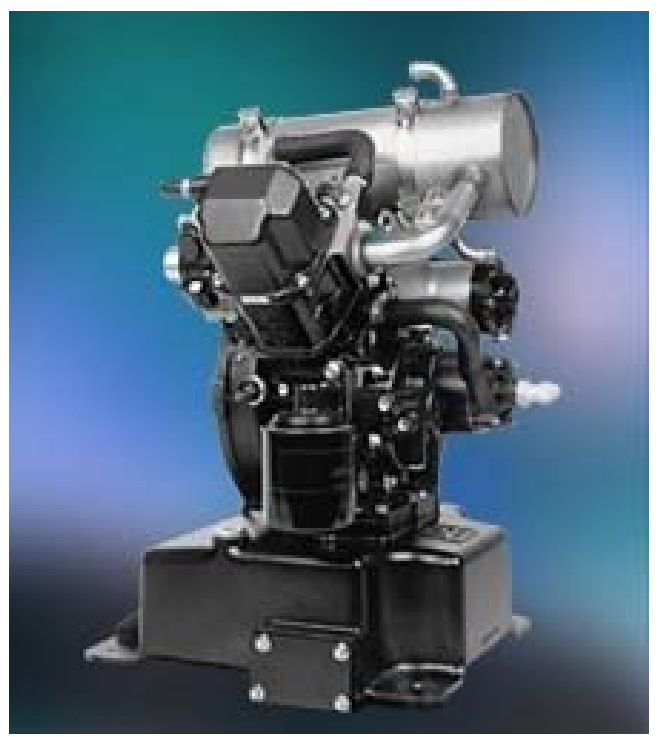

Figure 1 Engine identified for FFMHP.

Design of the first prototype (breadboard) was finalized in May 2011. The unit was designed to achieve a cooling capacity of 5 tons with a gas COP of 1.3 and a heating capacity of $75 \mathrm{kBtu} /$ hour with gas COP of 1.5 at ambient temperatures 95 and $47^{\circ} \mathrm{F}$ AHRI rating conditions, respectively. The unit was also designed to provide 60 gallon per day of domestic hot water at $140^{\circ} \mathrm{F}$ from engine heat recovery. The prototype was 72 inches long, 30 inches wide and 42 inches high. Figure 2 depicts the layout of major components to be installed in the breadboard cabinet including the engine, compressor, outdoor coil, refrigerant distributor and thermostatic expansion valve, the suction accumulator and oil separator, the refrigerant and domestic hot water heat exchangers and the connection locations for refrigerant to the separate indoor coil and the domestic hot water supply and return connections. 

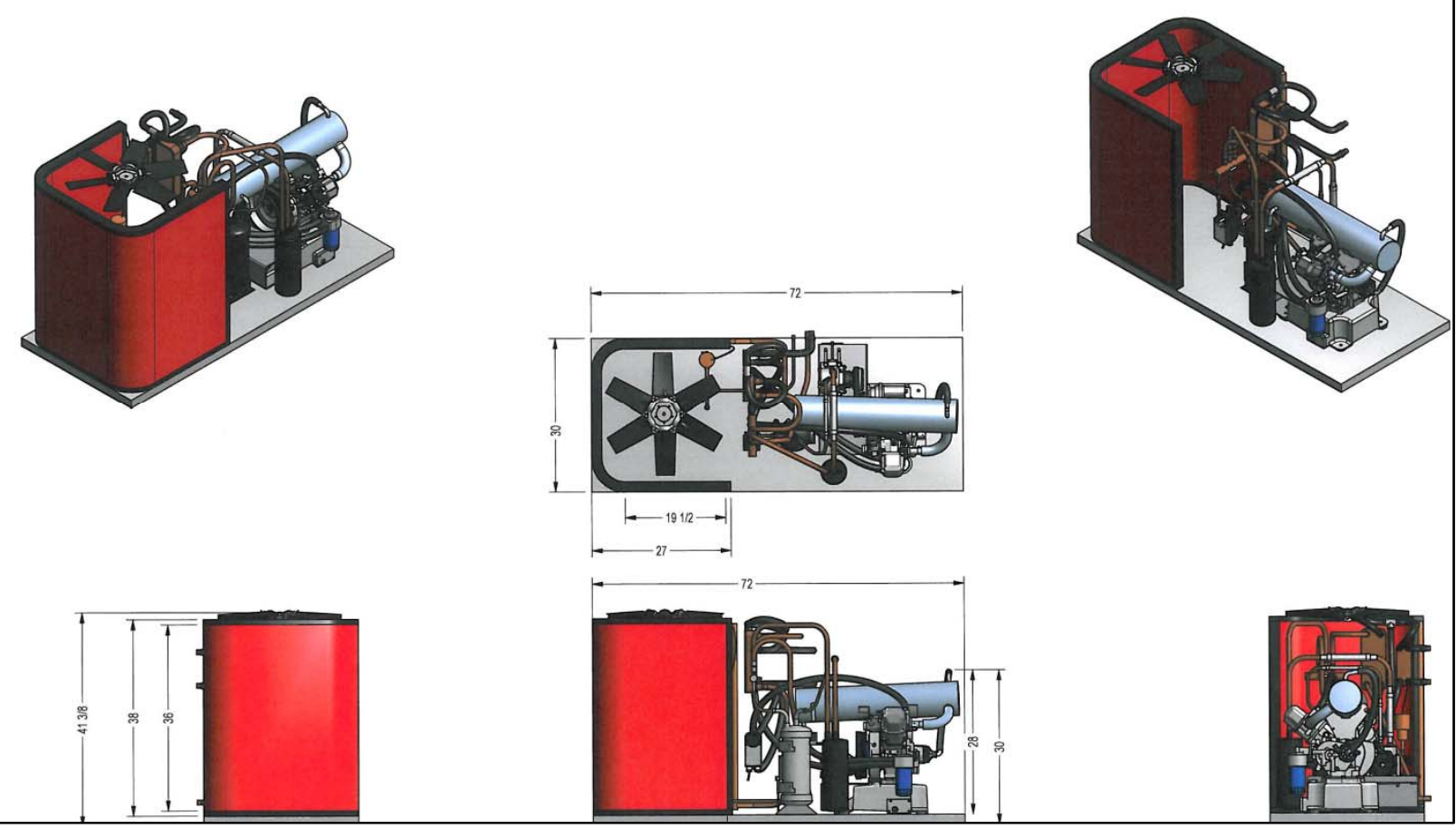

Figure 2 3D model of breadboard residential fuel fired multifunction heat pump.

Fabrication and assembly of the breadboard were completed in August 2011. The breadboard was delivered to ORNL. The initial test showed a cooling capacity, heat recovery rate and fuel consumption of 58, 40 and $64 \mathrm{kBtu} / \mathrm{hr}$ respectively at AHRI $95^{\circ} \mathrm{F}$ ambient condition. The engineering team from Marathon Engine Systems was present during the initial testing of the unit. Based on the initial test observation, the team made adjustments on air/fuel mixture and pulley size for better fuel economy. Testing showed that the engine did not have enough power at high ambient temperatures $\left(>110^{\circ} \mathrm{F}\right.$.

As a possible resolution it was decided to increase the compression ratio of the engine from 11 to 13.5 . This enabled the IC engine to run at higher load, higher ambient conditions, with less droop in speed. The team also advanced the ignition timing from 21 to $25^{\circ}$ for better fuel economy. After the adjustments, cooling performance tests at multiple ambient conditions were conducted throughout the month October 2011. As shown below in

Table 1, a gas cooling-only COP (cooling capacity divided by the fuel consumption) of 1.26 was achieved at $95^{\circ} \mathrm{F}$ ambient temperature (AHRI 210/240 test condition).

Table 1 Summary of cooling tests results.

\begin{tabular}{|c|c|c|c|c|c|c|c|c|}
\hline \multirow[t]{2}{*}{$\begin{array}{c}\text { Ambient } \\
\text { Temp }\end{array}$} & \multicolumn{2}{|c|}{ Speed } & \multicolumn{2}{|c|}{ Cooling Capacity } & \multirow[t]{2}{*}{$\begin{array}{c}\text { Fuel } \\
\text { Input }\end{array}$} & \multirow{2}{*}{$\begin{array}{c}\text { Heat } \\
\text { recovery } \\
\text { Domestic } \\
\text { HW } \\
\end{array}$} & \multicolumn{2}{|c|}{ Gas COP } \\
\hline & Engine & Compressor & & & & & $\begin{array}{c}\text { Cooling } \\
\text { only }\end{array}$ & $\begin{array}{l}\text { Cooling } \\
+\mathrm{HW}\end{array}$ \\
\hline${ }^{\circ} \mathrm{F}$ & $\mathrm{Rpm}$ & $\mathrm{Rpm}$ & $\mathrm{Btu} / \mathrm{hr}$ & r-Ton & $\mathrm{Btu} / \mathrm{hr}$ & $\mathrm{Btu} / \mathrm{hr}$ & & \\
\hline 95 & 2970 & 3341 & 59,862 & 5.0 & 47,522 & 21,149 & 1.26 & 1.70 \\
\hline 105 & 3400 & 3825 & 58,979 & 4.9 & 60,656 & 30,635 & 0.97 & 1.48 \\
\hline 110 & 3600 & 4050 & 58,864 & 4.9 & 70,208 & 39,295 & 0.84 & 1.40 \\
\hline 115 & 3330 & 3746 & 54,112 & 4.5 & 70,924 & 38,043 & 0.76 & 1.30 \\
\hline
\end{tabular}




\begin{tabular}{|l|l|l|l|l|l|l|l|l|}
120 & 2830 & 3184 & 45,734 & 3.8 & 58,984 & 35,339 & 0.78 & 1.37 \\
\hline
\end{tabular}

In addition, domestic hot water was supplied at rate of 21-39 kBtu/hr. In November 2011, the project team completed heating and part load cooling performance tests of the prototype FFMHP. As shown in the

Table 2 below, the unit achieved COPs of 2.05 and 1.98 at ambient temperatures of $82{ }^{\circ} \mathrm{F}$ and $95^{\circ} \mathrm{F}$ respectively. However, at part load conditions with lower engine speeds, the IC engine has not produced any recoverable heat for the domestic hot water.

Table 2 Part-load cooling test results.

\begin{tabular}{|c|c|c|c|c|c|c|c|}
\hline $\begin{array}{c}\text { Ambient } \\
\text { Temperature }\end{array}$ & \multicolumn{2}{|c|}{ Speed } & \multicolumn{2}{|c|}{ Cooling Capacity } & $\begin{array}{l}\text { Fuel } \\
\text { Input }\end{array}$ & $\begin{array}{c}\text { Heat } \\
\text { Recovery }\end{array}$ & $\begin{array}{l}\text { Gas } \\
\text { COP }\end{array}$ \\
\hline & Engine & Compressor & & & & & \\
\hline${ }^{\circ} \mathrm{F}$ & $\mathrm{rpm}$ & $\mathrm{rpm}$ & $\mathrm{Btu} / \mathrm{hr}$ & r-Ton & Btu/hr & $\mathrm{Btu} / \mathrm{hr}$ & \\
\hline 82 & 1200 & 1350 & 30,826 & 2.6 & 15,045 & 266 & 2.05 \\
\hline 95 & 1200 & 1350 & 26,974 & 2.2 & 13,612 & 914 & 1.98 \\
\hline
\end{tabular}

Several space heating performance tests at various engine speeds and ambient temperatures were also completed and results summarized in

Table 3. The highest COP achieved was 1.34 at the rating condition of $47^{\circ} \mathrm{F}$ and engine speed of $2991 \mathrm{rpm}$.

Table 3 Summary of results of space heating tests.

\begin{tabular}{|c|c|c|c|c|}
\hline Ambient Temperature & Engine Speed & Heating Capacity & Fuel Consumption & Gas COP \\
\hline${ }^{\circ} \mathrm{F}$ & $\mathrm{rpm}$ & $\mathrm{Btu} / \mathrm{hr}$ & $\mathrm{Btu} / \mathrm{hr}$ & \\
\hline 9.6 & 3607 & 43658 & 65423 & 0.67 \\
\hline 17.2 & 3610 & 49492 & 66238 & 0.75 \\
\hline 35.1 & 3598 & 66354 & 65006 & 1.02 \\
\hline 47.1 & 3636 & 77098 & 64672 & 1.19 \\
\hline 46.7 & 3392 & 72678 & 57918 & 1.26 \\
\hline 46.7 & 2991 & 65453 & 49020 & 1.34 \\
\hline 61.8 & 3228 & 82114 & 55223 & 1.49 \\
\hline 74.8 & 2760 & 76361 & 51993 & 1.47 \\
\hline
\end{tabular}

During the month of December 2011, the focus of project team was on the IC engine control logic and system controls integration. After weighing several options, the project team decided to implement a two module approach (system and engine) to control the IC engine and the heat pump system. The system control module (SCM) takes an input from the room thermostat and tells the engine to run at a certain speed based on thermostat demand, space heating or cooling mode, and compressor differential pressure. The SCM also signals gives a signal to the Engine Control Module (ECM) to start the engine 
and subsequently actuates the compressor clutch. The SCM controls the indoor blower and tells it to run on high or low based on thermostat stage and heat pump mode. The SCM is responsible for running the outdoor fan at appropriate times and also commands the engine cooling diverting valve based on an engine temperature supplied by the ECM. The SCM is responsible for providing all human interfaces through a touchpad. The SCM will send reset commands to the ECM if necessary for fault resolution. The ECM is responsible for starting and running the engine at the SCM commanded speed. It is responsible for energizing the engine starter, controlling the start sequence and timing, and turning on the gas valves. The ECM is responsible for controlling the throttle and mixture controls to maintain the desired speed under all conditions. The ECM signals back to the SCM vital operational data, including speed, engine coolant temperature, throttle position, mixture position, and engine faults.

In February 2012, design of the full-scale unit was completed and a prototype was delivered to ORNL's performance testing facility - see Figure 3. The outdoor coil size was increased from $17.5 \mathrm{sq}$. $\mathrm{ft}$. in the breadboard to $22.5 \mathrm{sq}$. $\mathrm{ft}$. to increase capacity and reduce discharge pressure at high ambient conditions.
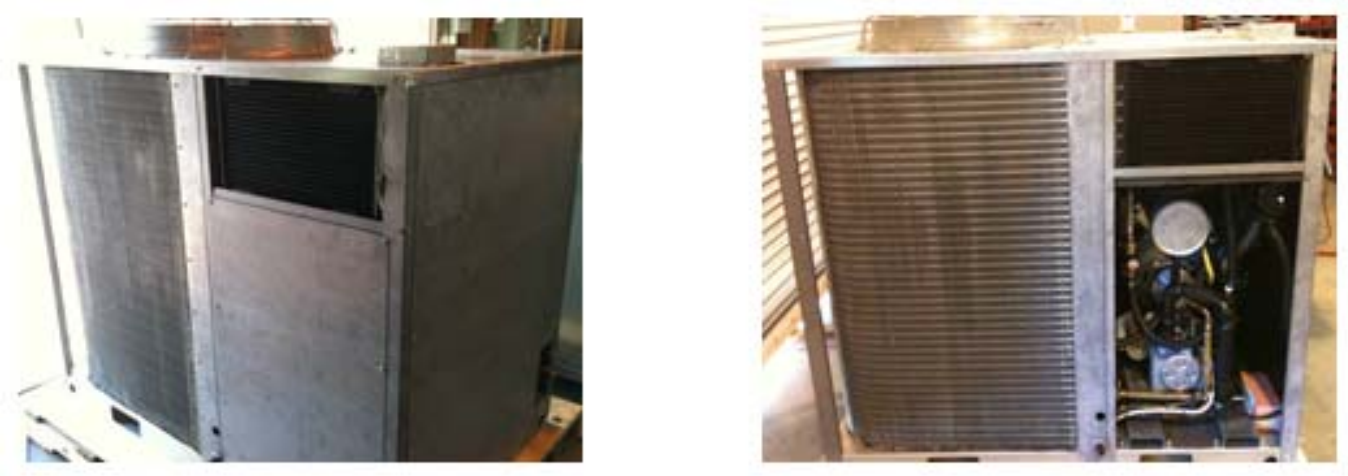

Figure 3 Second generation FFMHP prototype (full-scale unit)

Testing revealed that the radiator in the $2^{\text {nd }}$ generation prototype was not providing enough cooling to the engine. The design was changed to use an L-Shaped radiator parallel to the outdoor coil. In this configuration the ambient air passed through the DX coil and then to the radiator. In this configuration the inlet air to the radiator was higher. That required a larger surface area. However, it eliminated a separate radiator section including fan, motor and shroud.

The engine control strategy was changed to maintain wide open throttle and use the gas mixer to control the speed. It was proved through testing that higher efficiency could be realized by doing so. In order to mitigate the shortage of engine power at high ambient temperatures, the ECM was programmed to use the $\mathrm{O}_{2}$ sensor reading to only run the maximum reachable speed in the event that an unreachable speed is being requested by the SCM.

The $2^{\text {nd }}$ generation prototype was redesigned implementing the revised radiator and reprogrammed ECM and was delivered to ORNL in August 2012 (Refer to Figure 4.) Performance testing of the heat pump at various AHRI cooling and heating conditions was conducted in September 2012. 

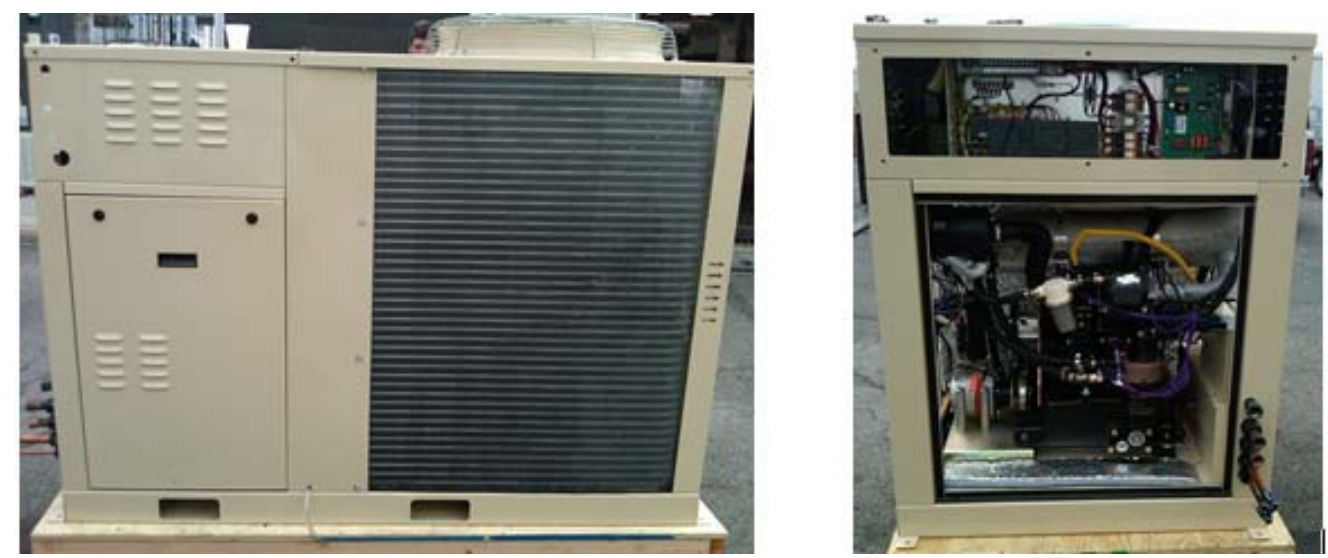

Figure 4 Second generation full-scale FFMHP unit.

In cooling mode, a capacity of $46.3 \mathrm{kBtu} / \mathrm{h}$ and gas coefficient of performance $\left(\mathrm{COP}_{\mathrm{G}}\right)$ of 1.26 was achieved at $95^{\circ} \mathrm{F}$ AHRI steady-state rating condition and 2409 engine rpm. In addition, the unit delivered $18.9 \mathrm{kBtu} / \mathrm{hr}$ of water heating capacity and raised unit overall $\mathrm{COP}_{\mathrm{G}}$ (space cooling + water heating) to 1.77. A summary of the results is inTable 4 Cooling mode $2^{\text {nd }}$ generation prototype test results.

Table 4 Cooling mode $2^{\text {nd }}$ generation prototype test results.

\begin{tabular}{|c|c|c|c|c|c|c|c|}
\hline $\begin{array}{c}\text { Engine } \\
\text { Speed }\end{array}$ & $\begin{array}{c}\text { Outdoor Air } \\
\text { Temperature } \\
\left({ }^{\circ} \mathbf{F}\right)\end{array}$ & $\begin{array}{c}\text { Cooling } \\
\text { Capacity } \\
(\mathbf{B t u} / \mathbf{h r})\end{array}$ & $\begin{array}{c}\text { Water } \\
\text { Heating } \\
\text { Capacity } \\
(\mathbf{B t u} / \mathbf{h r})\end{array}$ & $\begin{array}{c}\text { Fuel } \\
\text { Consumption } \\
(\mathbf{B t u} / \mathbf{h r})\end{array}$ & $\begin{array}{c}\mathbf{C O P}_{\mathrm{G}} \\
\text { With } \\
\text { Water } \\
\text { Heating }\end{array}$ & $\begin{array}{c}\text { System } \\
\mathbf{C O P} \\
\text { With Water } \\
\text { Heating }\end{array}$ & $\begin{array}{c}\text { Waste Heat } \\
\text { Recovered } \\
\mathbf{( \% )}\end{array}$ \\
\hline 1202 & 82 & 25293 & 7527 & 18130 & 1.81 & 1.33 & 41.5 \\
\hline 2400 & 82 & 49509 & 17141 & 39599 & 1.68 & 1.45 & 43.3 \\
\hline 1273 & 95 & 25178 & 9106 & 16789 & 2.05 & 1.49 & 54.5 \\
\hline 1661 & 95 & 32935 & 12919 & 24084 & 1.90 & 1.51 & 53.6 \\
\hline $\mathbf{2 4 0 9}$ & $\mathbf{9 5}$ & $\mathbf{4 6 3 8 4}$ & $\mathbf{1 8 8 9 0}$ & $\mathbf{3 6 7 8 8}$ & $\mathbf{1 . 7 7}$ & $\mathbf{1 . 5 2}$ & $\mathbf{5 1 . 4}$ \\
\hline 2818 & 95 & 52533 & 24422 & 46975 & 1.64 & 1.44 & 52.0 \\
\hline 3210 & 95 & 57527 & 29068 & 55158 & 1.57 & 1.41 & 52.7 \\
\hline 2248 & 105 & 39167 & 17089 & 35844 & 1.57 & 1.34 & 47.7 \\
\hline 3179 & 105 & 51967 & 29133 & 57096 & 1.42 & 1.28 & 51.0 \\
\hline 3188 & 115 & 47462 & 33978 & 62231 & 1.31 & 1.19 & 54.6 \\
\hline 3047 & 120 & 43118 & 33702 & 62249 & 1.23 & 1.12 & 54.1 \\
\hline 2652 & 125 & 36449 & 29198 & 54789 & 1.20 & 1.08 & 53.3 \\
\hline 2244 & 130 & 29146 & 23605 & 45399 & 1.16 & 1.02 & 52.0 \\
\hline
\end{tabular}

In heating mode, the unit delivered total capacity of $67.1 \mathrm{kBtu} / \mathrm{h}$ and $1.43 \mathrm{COP}_{\mathrm{G}}$ (including heat recovery) at $47^{\circ} \mathrm{F}$ AHRI steady-state rating condition and 2844 engine rpm. Figure 5 and Figure 6 show the heating capacity, water heating capacity and heating mode COP at different ambient temperatures for different engine speeds. 


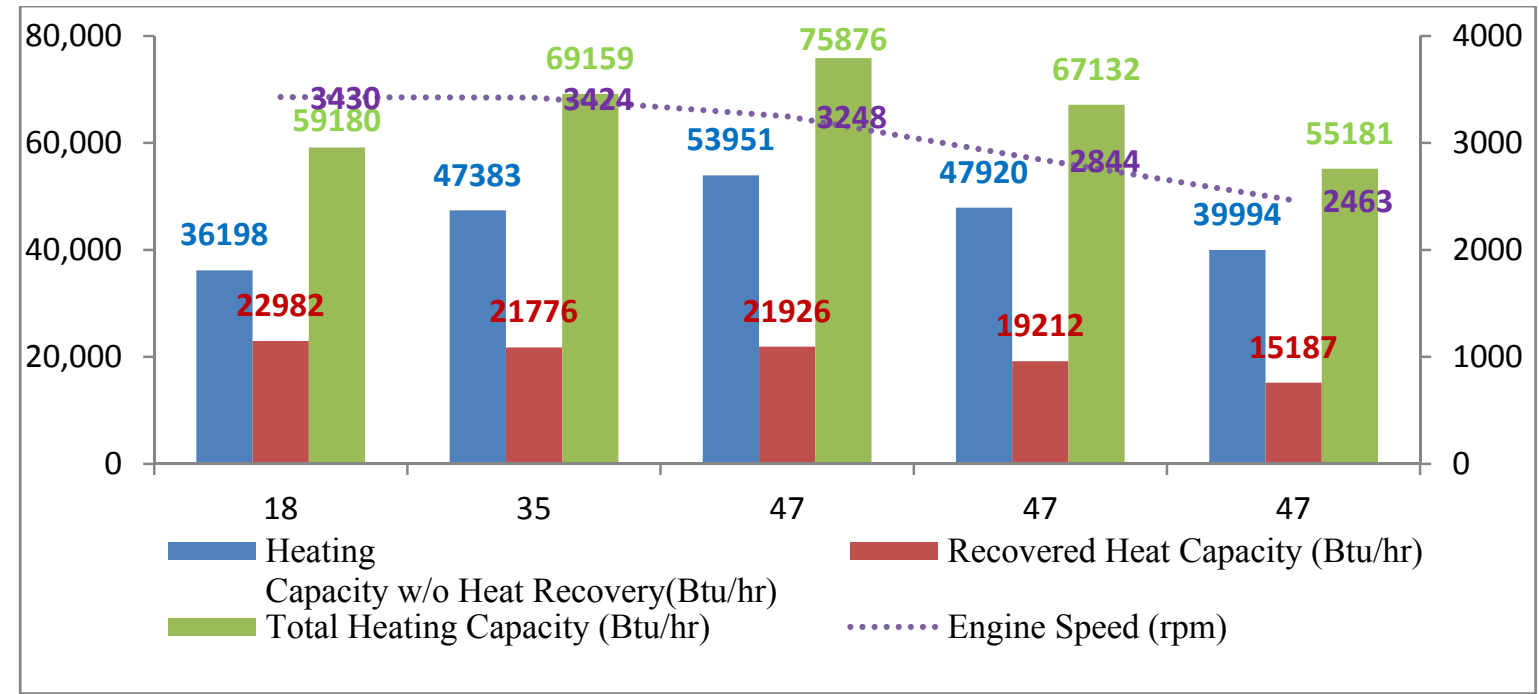

Figure 5 Heating capacity charts.

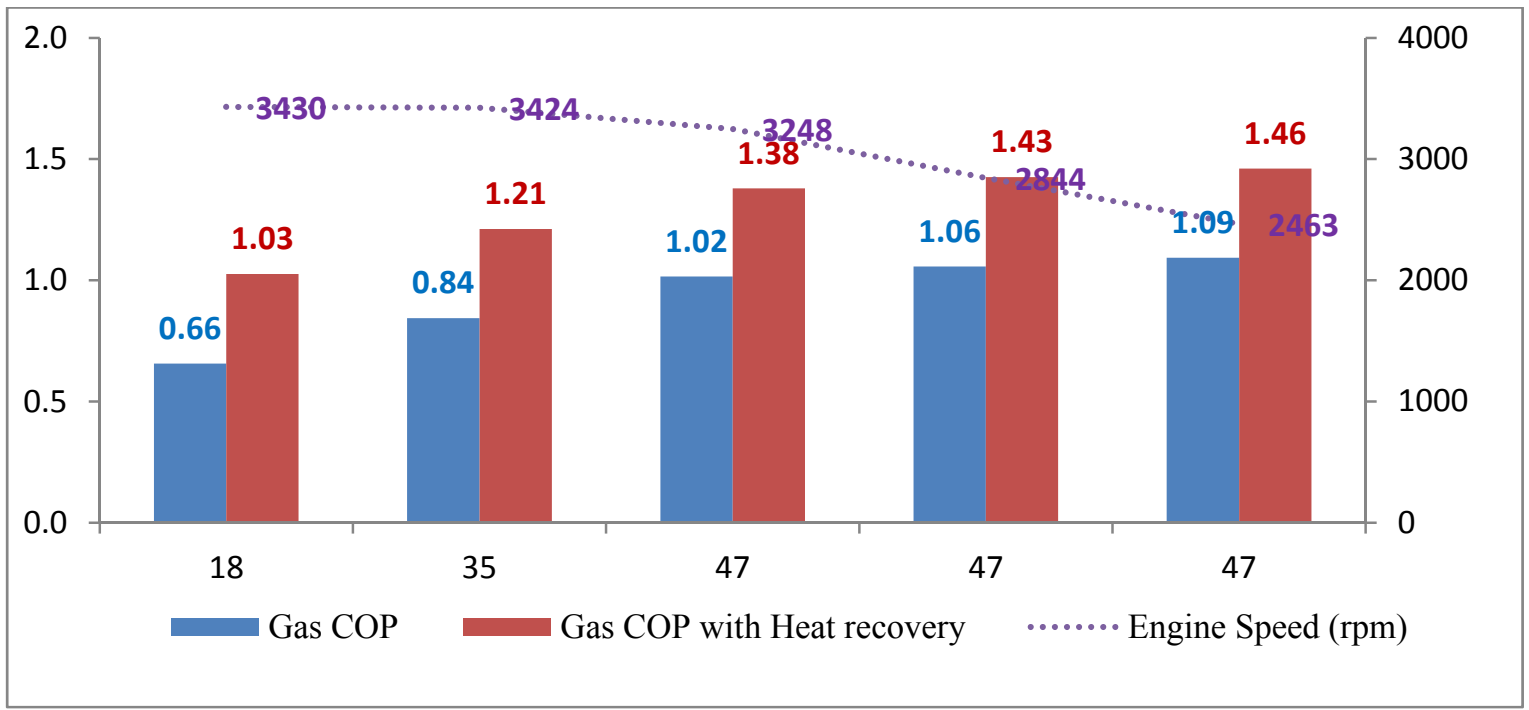

Figure 6 Heating mode COP charts.

The unit achieved $96.9 \%$ of the target $\mathrm{COP}_{\mathrm{G}}$ of 1.3 at the $95^{\circ} \mathrm{F}$ AHRI steady-state cooling rating condition. Based on the observed test results, the project design team researched additional energy saving potentials including: pulley ratios (between 1 and 1.125), increased engine compression ratio, fan motor, and refrigerant charge.

During October 2012, lab performance testing of the $2^{\text {nd }}$ generation unit continued at various outdoor temperature and engine speed. The project team reduced the engine exhaust back pressure by reconfiguring the piping system enabling an increase in engine power output. The performance tests were conducted using the 1:1 and 1:1.125 compressor to engine pulley ratios. The lab test results are summarized in

Table 5 and

Table 6. 
Table 5 Cooling performance lab testing results with the 1:1 compressor to engine pulley ratio.

\begin{tabular}{|c|c|c|c|c|c|c|}
\hline $\begin{array}{c}\text { Engine } \\
\text { Speed }\end{array}$ & $\begin{array}{c}\text { Outdoor Air } \\
\text { Temperature } \\
\mathbf{(} \mathbf{F} \text { F) }\end{array}$ & $\begin{array}{c}\text { Cooling } \\
\text { Capacity } \\
\mathbf{( B t u} / \mathbf{h r})\end{array}$ & $\begin{array}{c}\text { Cooling } \\
\text { Capacity } \\
\text { (r-ton) }\end{array}$ & $\begin{array}{c}\text { Water } \\
\text { Heating } \\
\text { Capacity } \\
\text { (Btu/hr) }\end{array}$ & $\begin{array}{c}\text { Gas COP } \\
\text { Without } \\
\text { Water } \\
\text { Heating }\end{array}$ & $\begin{array}{c}\text { Gas COP } \\
\text { With Water } \\
\text { Heating }\end{array}$ \\
\hline 2400 & 95 & 44779 & 3.7 & 20137 & 1.20 & 1.73 \\
\hline 3214 & 95 & 55811 & 4.7 & 29900 & 1.03 & 1.58 \\
\hline 3219 & 115 & 45262 & 3.8 & 35947 & 0.69 & 1.25 \\
\hline 2998 & 120 & 39494 & 3.3 & 33859 & 0.65 & 1.21 \\
\hline 2530 & 125 & 34447 & 2.9 & 28196 & 0.68 & 1.25 \\
\hline 1752 & 130 & 21171 & 1.8 & 18462 & 0.63 & 1.19 \\
\hline
\end{tabular}

Table 6 Cooling performance lab testing results with the 1:1.125 compressor to engine pulley ratio.

\begin{tabular}{|c|c|c|c|c|c|c|}
\hline $\begin{array}{c}\text { Engine } \\
\text { Speed }\end{array}$ & $\begin{array}{c}\text { Outdoor Air } \\
\text { Temperature } \\
\mathbf{(} \mathbf{F})\end{array}$ & $\begin{array}{c}\text { Cooling } \\
\text { Capacity } \\
\mathbf{( B t u} / \mathbf{h r})\end{array}$ & $\begin{array}{c}\text { Cooling } \\
\text { Capacity } \\
\mathbf{( r - t o n )}\end{array}$ & $\begin{array}{c}\text { Water } \\
\text { Heating } \\
\text { Capacity } \\
\mathbf{( B t u / h r )}\end{array}$ & $\begin{array}{c}\text { Gas COP } \\
\text { Without } \\
\text { Water } \\
\text { Heating }\end{array}$ & $\begin{array}{c}\text { Gas COP } \\
\text { With Water } \\
\text { Heating }\end{array}$ \\
\hline 2401 & 95 & 48488 & 4.0 & 18969 & 1.24 & 1.72 \\
\hline 3200 & 95 & 59308 & 4.9 & 33353 & 1.01 & 1.56 \\
\hline 2455 & 115 & 40982 & 3.4 & 27982 & 0.82 & 1.39 \\
\hline 1856 & 120 & 29075 & 2.4 & 20426 & 0.80 & 1.37 \\
\hline 1385 & 125 & 18374 & 1.5 & 14911 & 0.71 & 1.28 \\
\hline
\end{tabular}

Table 6 shows that the unit was able to run above $125^{\circ} \mathrm{F}$ outside air using the bigger 1.125 engine pulley. With the $1^{\text {st }}$ generation prototype operation, the 1:1.125 pulley ratios (larger engine pulley) were limited to outdoor air inlet temperatures below $121^{\circ} \mathrm{F}$. The bigger engine pulley size will allow us to run the engine at lower speed and fuel consumption resulting in improved system efficiency.

In November 2012, multiple tests in heating mode were conducted. Initial test results showed elevated refrigerant discharge temperatures at low ambient temperature (high compression ratio) test conditions. In the current heat recovery method, the engine waste heat is captured by increasing the suction refrigerant superheat. When the suction temperature lifted to $125^{\circ} \mathrm{F}$, the discharge temperature reached $234^{\circ} \mathrm{F}$. To mitigate this problem, the sensing bulb of the thermal expansion valve (TXV) was relocated from the outlet of the evaporator coil to the outlet of the heat recovery heat exchanger (engine coolant to suction refrigerant). In this configuration, the refrigerant will leave the evaporator two phase and be superheated by the recovered engine waste heat. The refrigerant suction and discharge temperatures were kept below the high temperature limits of the compressor after relocating the TXV bulb.

After resolving the high discharge temperature concern, the project team continued testing in heating mode at the rated $47^{\circ} \mathrm{F}, 35^{\circ} \mathrm{F}$ frost accumulation case and $17^{\circ} \mathrm{F}$ low ambient conditions. The results are summarized in Table 7. 
Table 7 Heating performance lab testing results.

\begin{tabular}{|c|c|c|c|c|c|}
\hline $\begin{array}{c}\text { Outdoor Air } \\
\text { Temperature } \\
\left({ }^{\circ} \mathrm{F}\right)\end{array}$ & $\begin{array}{c}\text { Engine } \\
\text { Speed } \\
(\mathrm{rpm})\end{array}$ & $\begin{array}{c}\text { Return Air } \\
\text { Temperature } \\
\left({ }^{\circ} \mathrm{F}\right)\end{array}$ & $\begin{array}{c}\text { Supply Air } \\
\text { Temperature } \\
\left({ }^{\circ} \mathrm{F}\right)\end{array}$ & $\begin{array}{c}\text { Heating } \\
\text { Capacity } \\
(\mathrm{Btu} / \mathrm{hr})\end{array}$ & $\begin{array}{c}\text { Gas } \\
\text { COP }\end{array}$ \\
\hline 17.5 & 3514 & 70.2 & 93.5 & 51426 & 0.81 \\
\hline 35.1 & 3498 & 69.9 & 100.3 & 65028 & 1.00 \\
\hline 47.2 & 3510 & 70.0 & 106.4 & 77808 & 1.14 \\
\hline 47.2 & 2761 & 70.5 & 99.9 & 61505 & 1.26 \\
\hline
\end{tabular}

The COP at the rated condition $\left(47^{\circ} \mathrm{F}\right)$ was $16 \%$ lower than the design target. The project team identified additional energy savings, fuel input reduction, and cost reduction areas.

In January 2013, a new SCM development was completed to replace the programmable logic controller (PLC) originally used (Figure 7.) The new system control module was comprised of two offthe-shelf boards; Arduino Mega 2560 (Figure 8) and a BeagleBone unit (Figure 9.) The Arduino performed all the control functions while the BeagleBone acted as the human-machine-interface and a data logger.

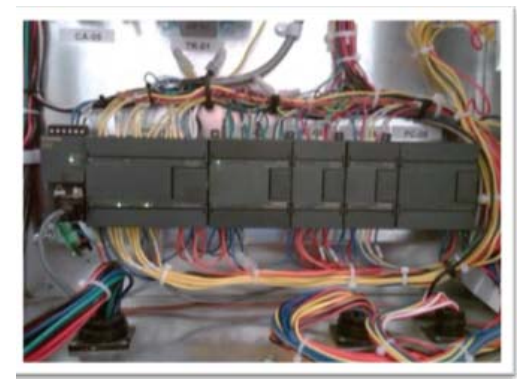

Figure 7 Original PLC used as the control module of the heat pump.

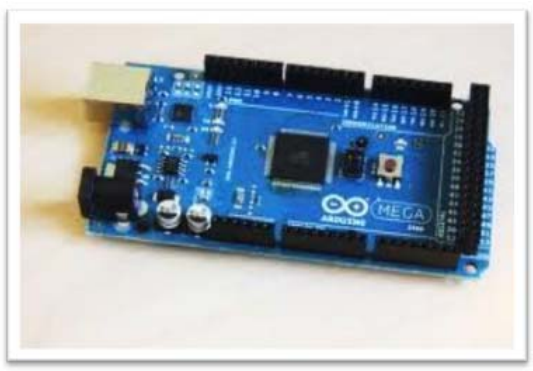

Figure 8 Arduino Mega 2560 that replaced the PLC.

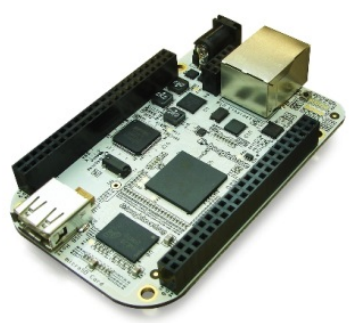

Figure 9 BeagleBone board.

The new control module (Arduino-BeagleBone) costs significantly less than the PLC while allowing more flexibility due to the higher number of I/O points available on the board compared to the PLC. 
After evaluating heating mode test results, the project team decided to re-design the heat recovery loop. The re-designed loop (Figure 10) used one thermostatic valve and an electronic modulating valve to control the flow of coolant. The modulating valve was controlled by sensing the outlet coolant temperature from the heat recovery heat exchanger and suction refrigerant temperature below $135^{\circ} \mathrm{F}$. This upgrade would allow for the correct amount of heat recovery while preventing high discharge refrigerant temperatures.

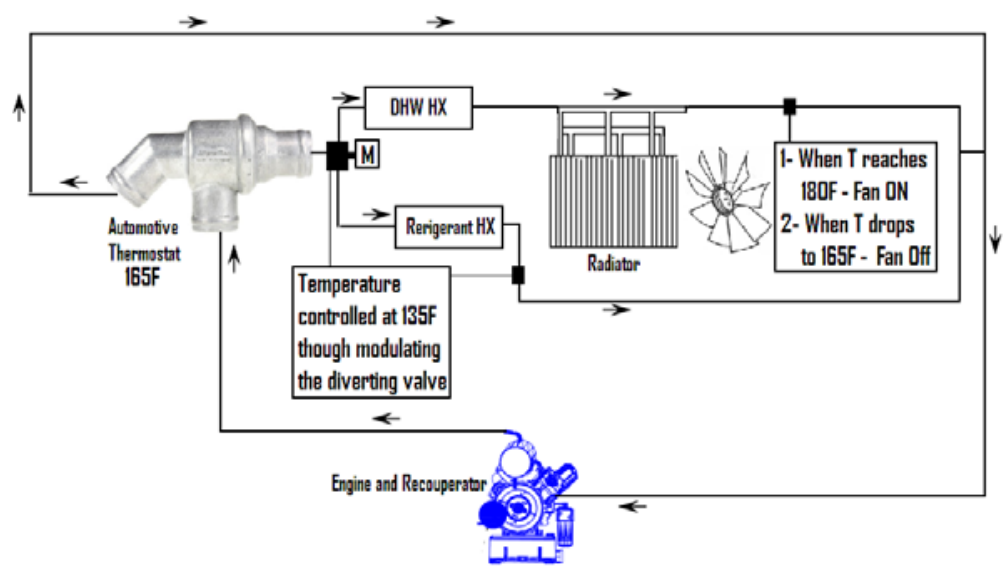

Figure 10 Modified design of heat recovery circuit.

In order to reduce component counts and cost, the project team decided to change the current belt driven compressor assembly to a direct coupled arrangement pictured in Figure 11. This would also eliminate some inefficiency associated with the belt.

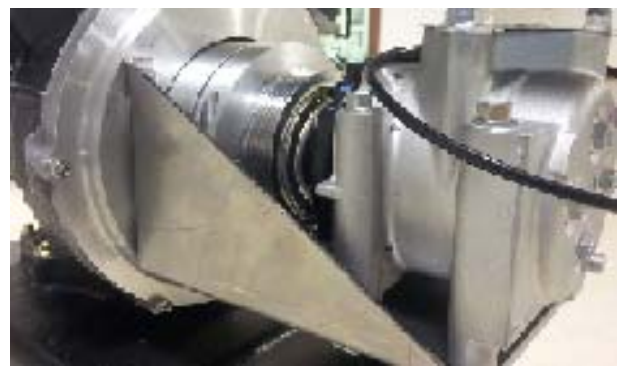

Figure 11 Compressor directly couple to engine flywheel.

The changes were implemented in a new build. During field testing of the revised prototype the new components did not perform as required. The direct coupling failed consistently on all units. The newly developed SCM suffered electric noise issues on some units.

Attempts to resolve the issues were unsuccessful so it was decided to go back to the original belt drive and PLC controller. A new prototype (Beta) FFMHP was built and was delivered to ORNL in September 2013. A total of 21 tests were completed on the Beta unit. Both cooling and heating mode tests were run for a range of engine speeds, and outdoor \& indoor temperatures. The following table summarizes the details of the test conditions: 
Table 8 Testing conditions for Beta prototype.

\begin{tabular}{|c|c|c|c|c|c|c|}
\hline $\begin{array}{c}\text { Exp. } \\
\#\end{array}$ & Mode & $\mathrm{T}_{\text {Out Door }}\left({ }^{\circ} \mathrm{F}\right)$ & $\begin{array}{c}\mathrm{T}_{\text {Indoor }}\left({ }^{\circ} \mathrm{F}\right), \\
\mathrm{T}_{\text {Dew }}\left({ }^{\circ} \mathrm{F}\right)\end{array}$ & $\begin{array}{l}\text { Engine } \\
\text { RPM }\end{array}$ & Reason & Note/Issue \\
\hline 1 & Cooling & 82 & 80,51 & 1800 & Test & $2 \varphi$ flow \\
\hline 2 & Cooling & 82 & 80,51 & 2600 & Test & No \\
\hline 3 & Cooling & 82 & 80,51 & 2600 & Repeated & No \\
\hline 4 & Cooling & 82 & 80,51 & 3400 & Test & No \\
\hline 5 & Cooling & 95 & 80,51 & 3400 & Test & No \\
\hline 6 & Cooling & 95 & 80,51 & 2600 & Test & No \\
\hline 7 & Cooling & 95 & 80,51 & 1800 & Test & No \\
\hline 8 & Cooling & 95 & 80,51 & 3400 & Repeated & No \\
\hline 9 & Cooling & 105 & 80,51 & 3400 & Test & No \\
\hline 10 & Cooling & 115 & 80,51 & 3400 & Test & $\mathrm{No}$ \\
\hline 11 & Cooling & 120 & 80,51 & 2700 & Test & Engine overloaded \\
\hline 12 & Cooling & 125 & 80,51 & 2075 & Test & Engine overloaded \\
\hline 13 & Heating & 62 & 70 & 3400 & Test & Some Noise \\
\hline 14 & Heating & 62 & 70 & 2600 & Test & Some Noise \\
\hline 15 & Heating & 47 & 70 & 3400 & Test & Some Noise \\
\hline 16 & Heating & 47 & 70 & 2600 & Test & Some Noise \\
\hline 17 & Heating & 35 & 70 & 3400 & Test & Some Noise \\
\hline 18 & Heating & 17 & 70 & 3400 & Test & No \\
\hline 19 & Heating & 17 & 78 & 3400 & Test & No \\
\hline 20 & Heating & 35 & 78 & 3400 & Test & No \\
\hline 21 & Heating & 47 & 78 & 3400 & Test & No \\
\hline
\end{tabular}

Cooling capacity, water heating capacity and gas COP are shown in Figure 12.
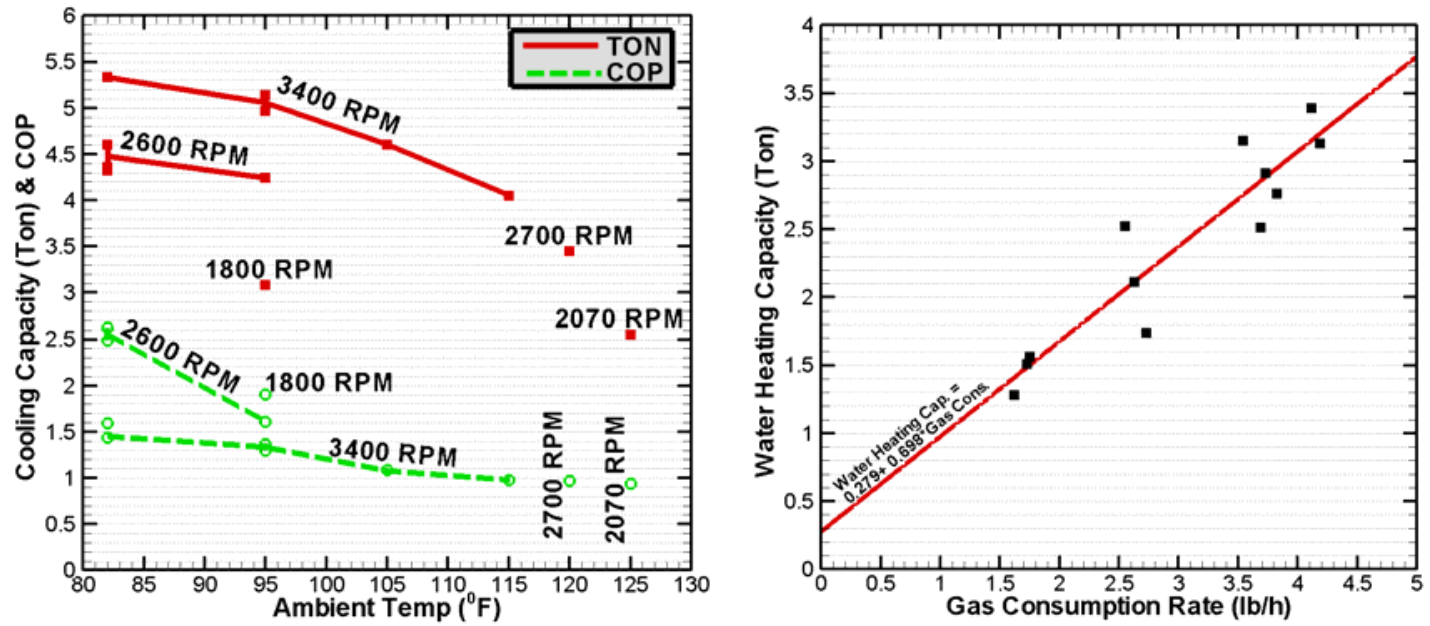

Figure 12 Cooling capacity and COP (left) and water heating capacity (right) of Beta prototype.

Heating capacity, water heating capacity and gas COP are shown in Figure 13. 

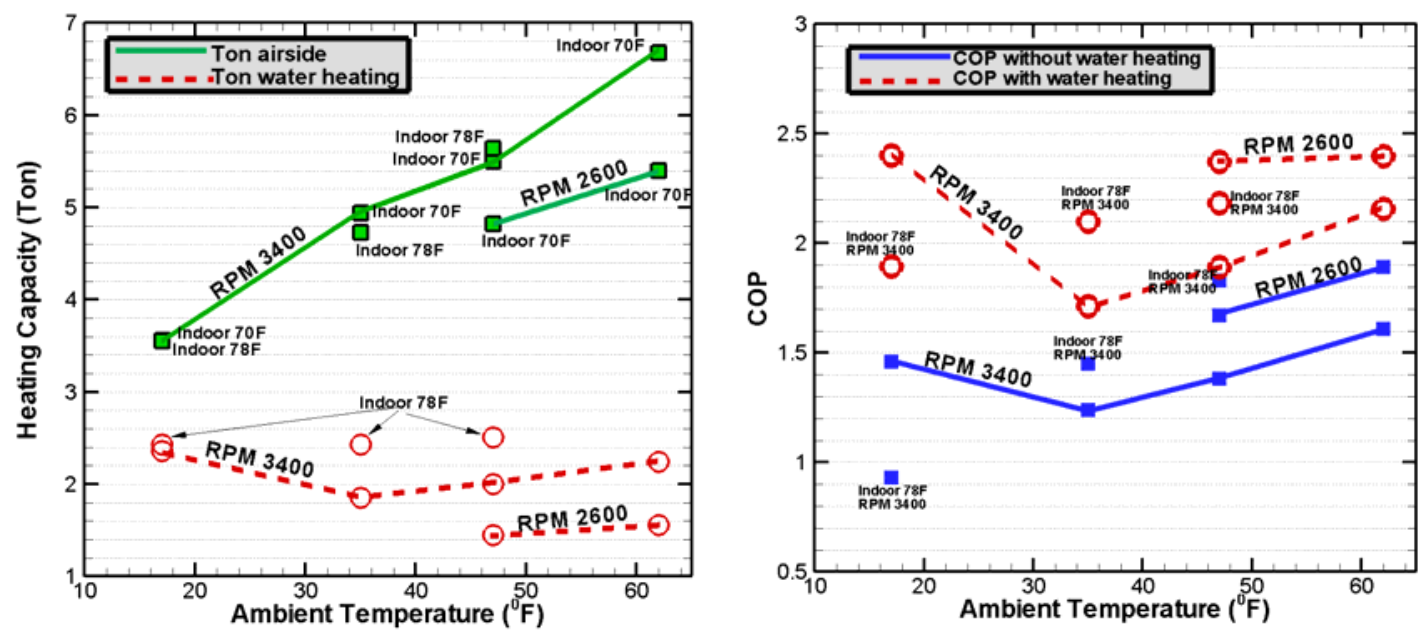

Figure 13 Heating capacity and water heating capacity (left) and gas COP (right) of Beta prototype.

In order to increase the primary energy efficiency of the FFMHP prototype, the potential of adding a generator was explored. In April 2013, the project team completed the design of a 5-ton black-start packaged unit with an auxiliary electric generation option and domestic water heating. The technology utilizes a built-for-purpose $950 \mathrm{cc}$ natural gas fueled engine, scroll compressor, a high efficiency generator and waste heat recovery heat exchangers to provide heat to the building's domestic hot water system. It also includes:

- a battery system (charged by the electric generator) to enable starting the unit in the event grid power is unavailable (grid outage, etc.)

- capability to operate as a stand-by generator type system, and

- control systems to operate the unit based upon the requirements and priority of the unit's output (i.e. cooling, heat, electric generation, hot water.)

The black-start prototype FFMHP unit was delivered to ORNL in September 2013. A total of 47 tests were carried out in both cooling and heating modes for a range of operating conditions including: engine speed, electricity generation and outdoor $\&$ indoor temperatures.

Figure 14 and Figure 15 show the cooling and heating capacity, water heating capacity, and electric power generation for the onboard air handler and the gas COP of the unit in the cooling mode at 1650 and 2200 RPM. NOTE - for these tests the engine is generating all the electric power required for the system air handler and other electricity consuming components but NO electric power is being exported for external uses.

In cooling mode (Figure 14), The COP of the unit is insensitive to the engine speed for these two speed settings. It can be seen that the system continuously provides about 2300 watts electric power to the onboard air handler. Note that the gas COP in these figures does not include the electric power provided to the air handler.

In heating mode, The COP of the unit is slightly higher at the higher engine RPM. It was noticed that the power generation to the air handler increases when the heating capacity goes beyond about 5 Ton. The gas COP for the black start unit does not include the power generation for the air handler. 

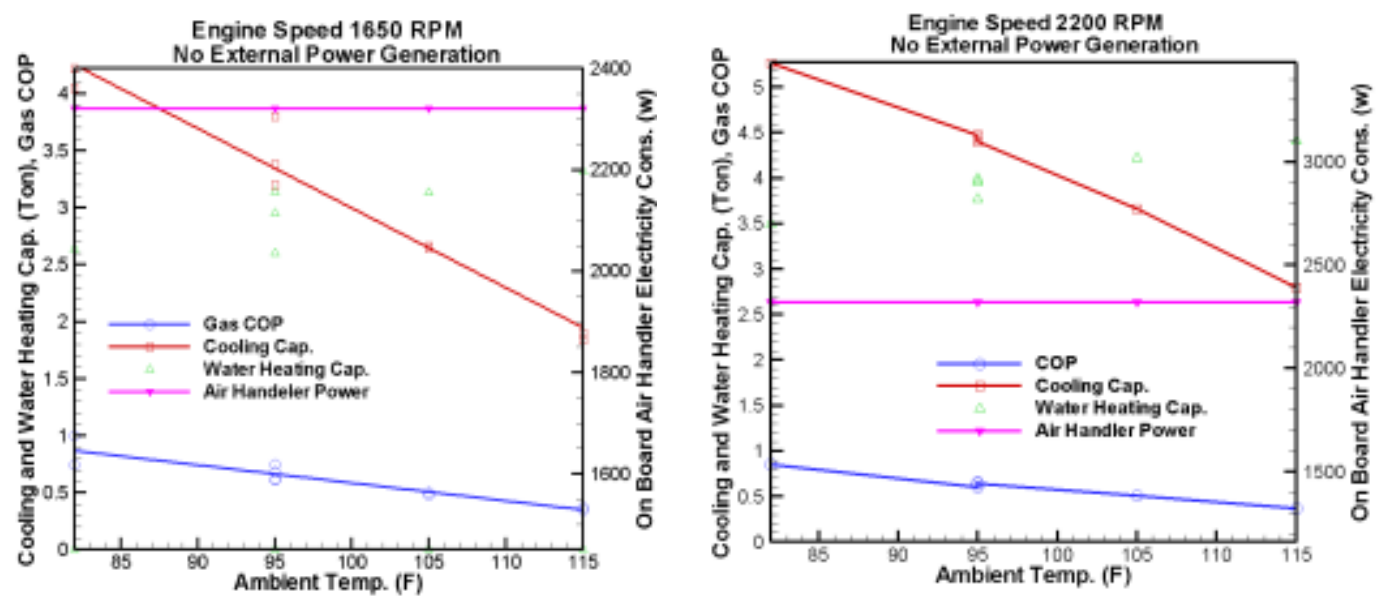

Figure 14 Cooling capacity, water heating capacity, and gas COP (no auxiliary power.)
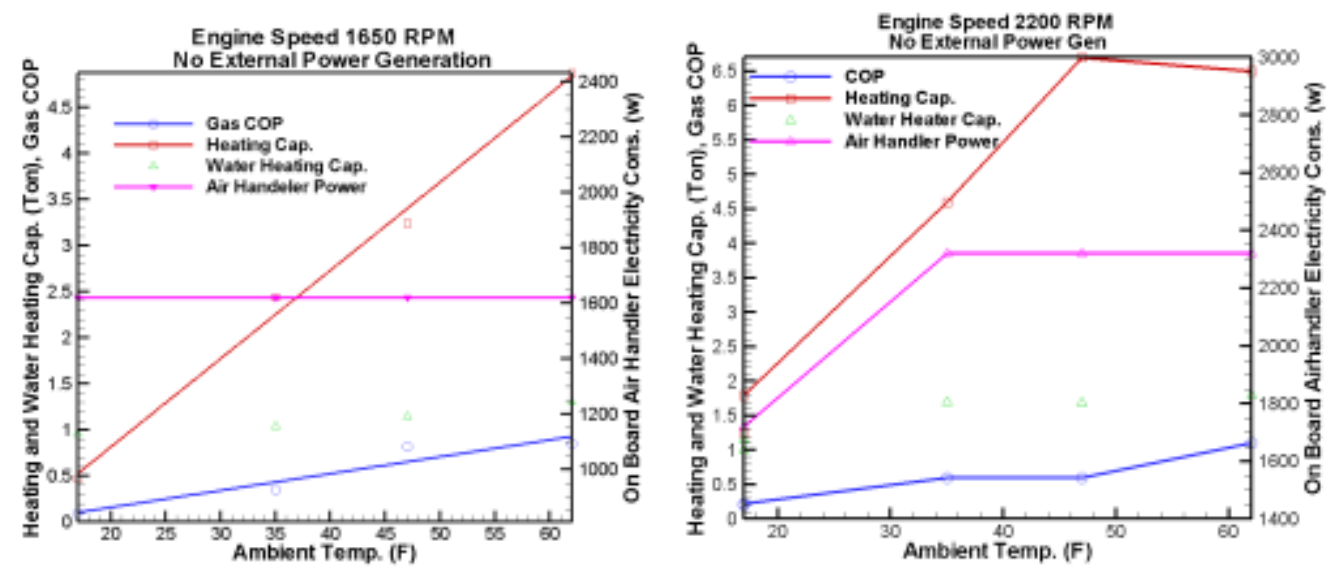

Figure 15 Heating capacity, water heating capacity, and gas COP (no auxiliary power.)

Figure 16 and Figure 17 show the cooling and heating capacity, water heating capacity and gas COP while providing auxiliary power. The unit cooling mode performance at a constant ambient temperature of $95^{\circ} \mathrm{F}$ at two engine speed settings are shown in Figure 16. At 1650 RPM (low speed setting) the engine could not generate more than 1000 watt for external uses. Pushing the engine to provide more external electric power generation led to the engine stalling. Therefore, such operation is not recommended in the field. At high speed (2200 RPM) setting, however, the system could reliably produce external electric power as high as 2200 watts with no significant change in the cooling power. 

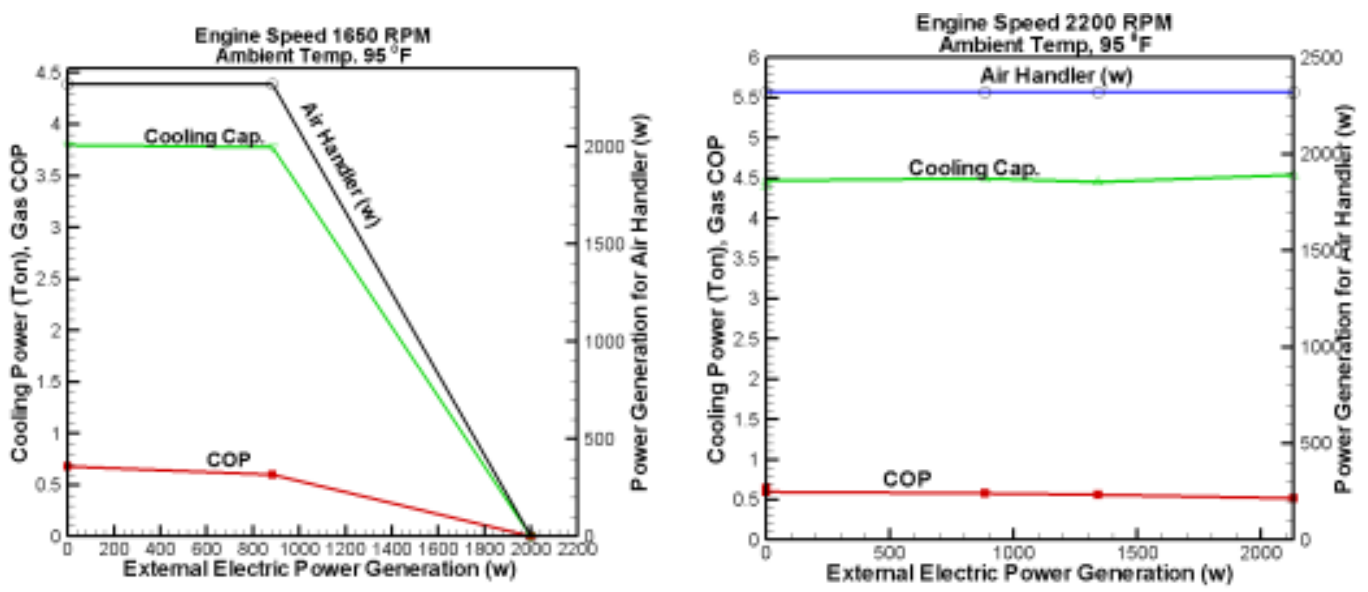

Figure 16 Cooling capacity and gas COP vs external auxiliary power output.

In order to prevent engine stall, the power generation test in heating mode was only performed at high engine RPM. The heating mode performance at a constant ambient temperature of $47{ }^{\circ} \mathrm{F}$ at high engine speed settings is shown in Figure 17. At 2200 RPM (high speed setting) the engine could generate more than 2200 watt for external uses. The system heating capacity dropped from about 6.5 tons to 4.5 tons as the external power generation went from 0 to 800 watt but remained fairly constant for higher power generation rates.

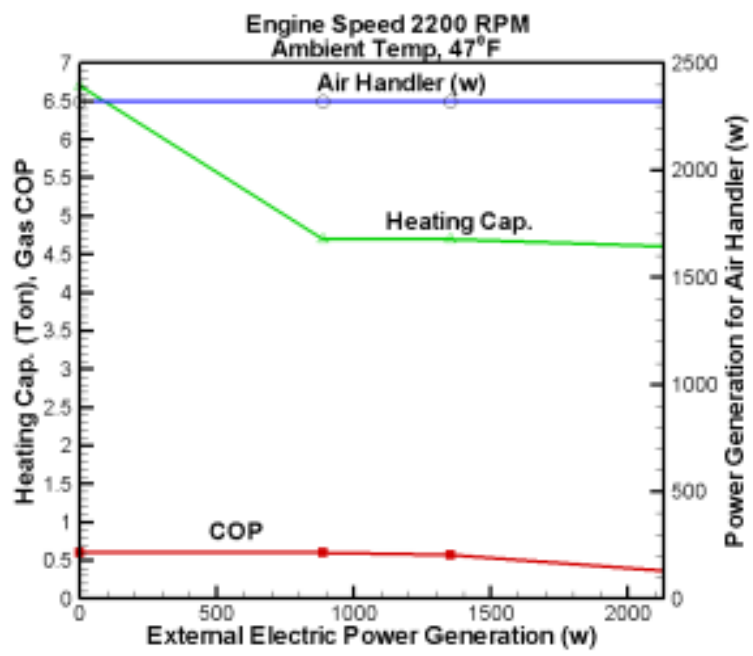

Figure 17 Heating capacity and gas COP vs external auxiliary power output.

In January 2014, the project team decided to install a lower cost DC generator (Delco-Remy 33SI) replacing the original high cost unit. The cost of the new generator was about $\$ 500$ plus $\$ 100$ for a DC-toAC transformer vs. about $\$ 6000$ for the original generator. 


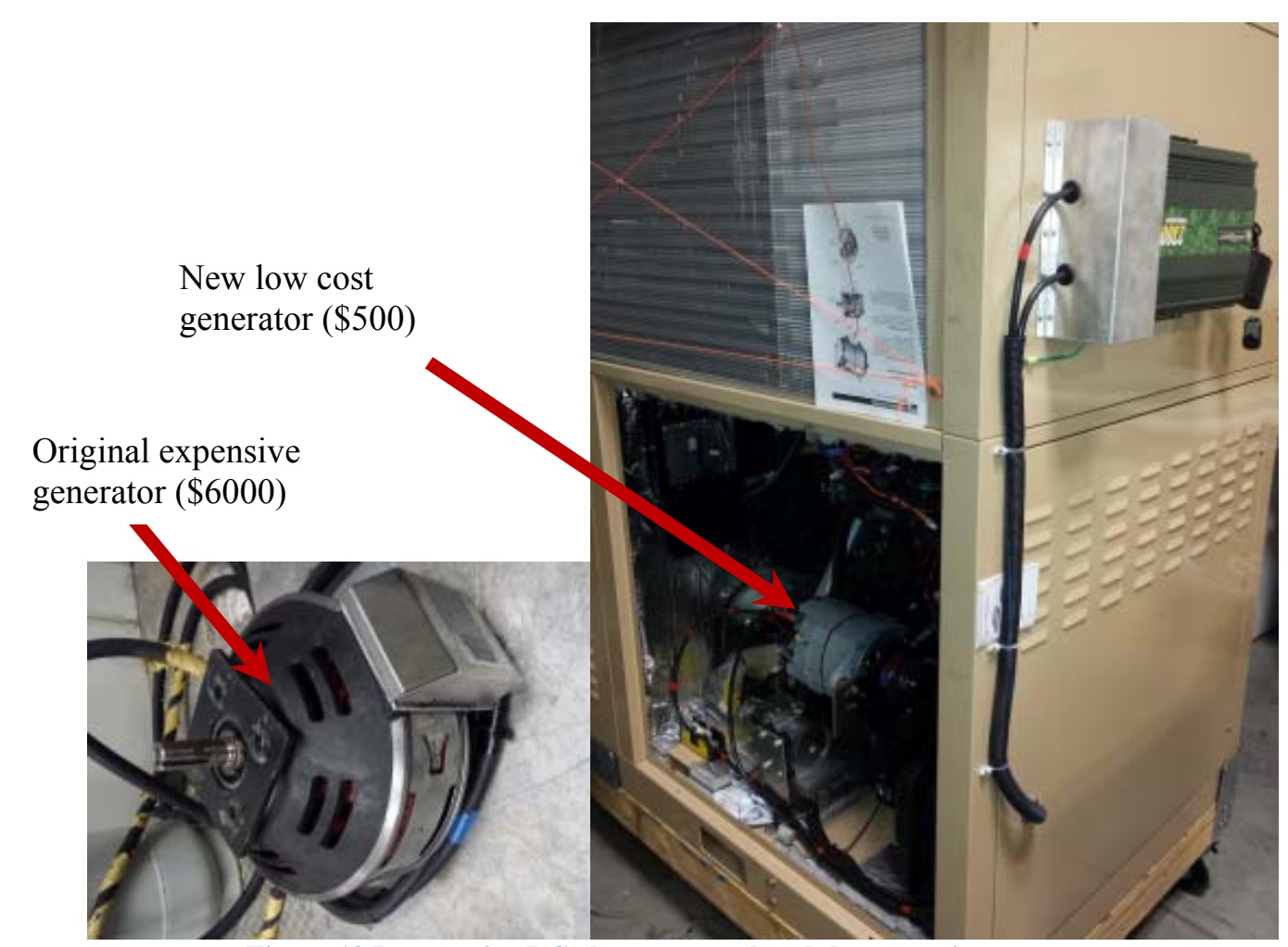

Figure 18 Inexpensive DC alternator replaced the expensive generator.

The black-start unit was tested in cooling mode at $95^{\circ} \mathrm{F}$ ambient temperature. Figure 19 summarizes the performance of the system at different conditions. The internal power generation was always producing about $1.5 \mathrm{~kW}$ for the indoor and outdoor fans. At $1600 \mathrm{RPM}$ and zero external power extraction, the cooling capacity was 5.2 Ton. However, in this low RPM, as soon we extracted $0.4 \mathrm{~kW}$ of the power, the cooling capacity drops to 3 Ton. Further increase in external electricity load, will lead to engine stall.

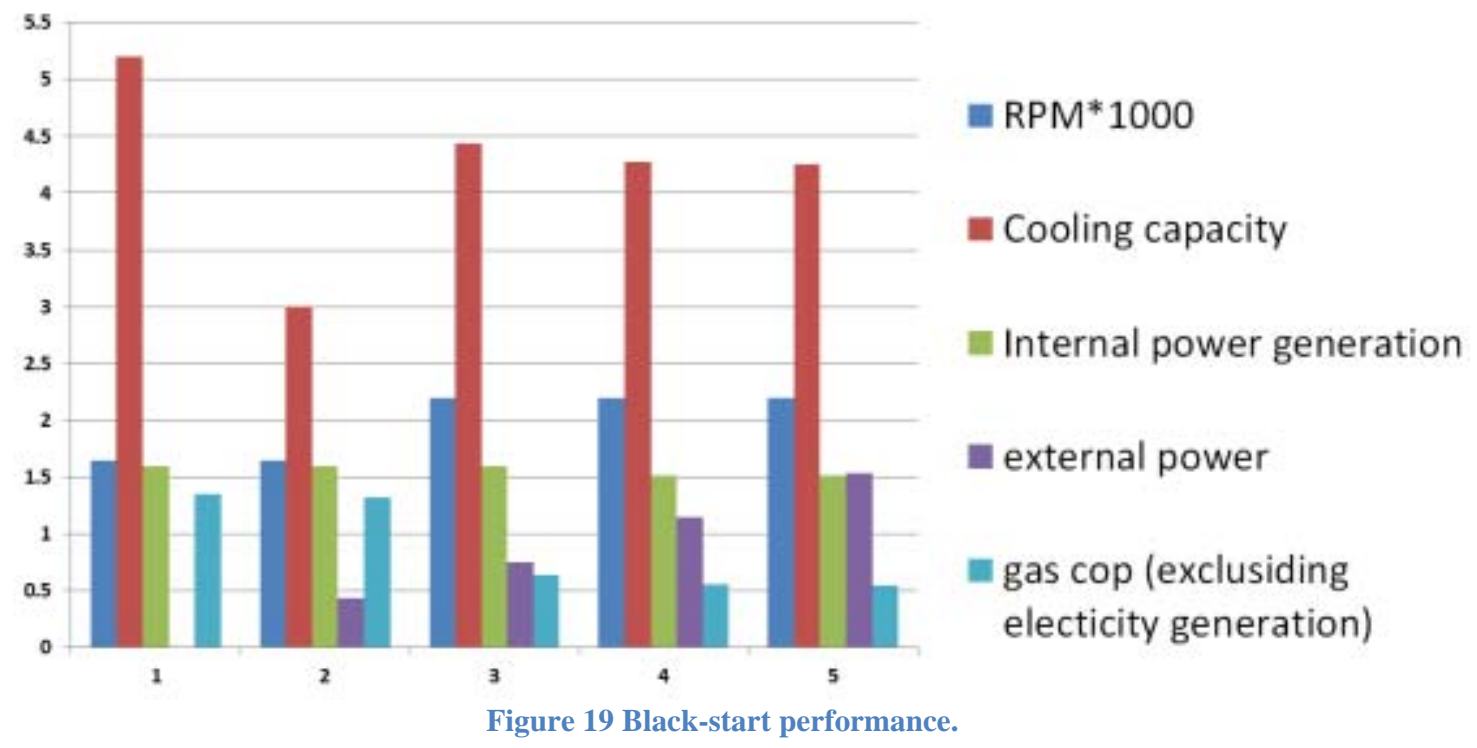


At 2200 RPM (high speed), however, the engine produces much more power but at lower efficiency. At high speed, the gas COP is lower but the engine has enough power to generate up to $1.6 \mathrm{~kW}$ of electricity without significantly losing the cooling capacity. This is enough power to run the important household appliances during emergency grid power loss. ORNL testing reveals that the natural gas to electricity generation performance of the unit is between 12-20\% (not including hot water production). This fairly low gas to electricity conversion efficiency was attributed to the inversion losses of the DC generator output to AC to power the fan motors. To avoid these losses, a single 5000 Watt, NorthStart (GG0048) AC generator was installed. The generator will produce approximately $1.6 \mathrm{~kW} \mathrm{AC} \mathrm{power} \mathrm{for} \mathrm{indoor} \mathrm{and}$ outdoor fans and produce approximately $1-2 \mathrm{~kW}$ of external electricity for emergency needs such as lighting, refrigerator, computers and etc. It was expected that average electricity demand from the generator to be in the range of $2-3 \mathrm{~kW}$ (40 to $60 \%$ of rated output) in which the $5 \mathrm{~kW}$ generator efficiency is fairly high.

A pre-commercial prototype of the FFMHP was built and delivered to ORNL in September 2014 (Figure 20.) The prototype was tested at various AHRI conditions. Testing conditions, capacity, and gas COP are listed in

Table 9.

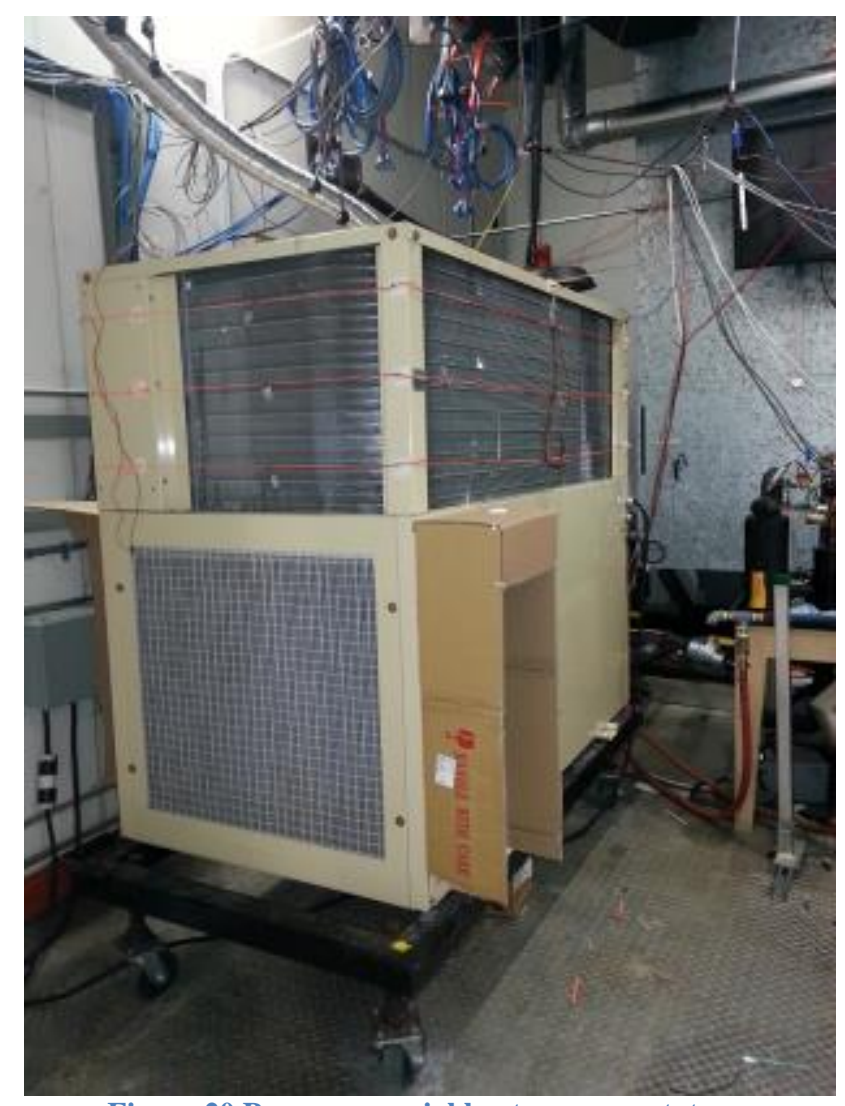

Figure 20 Pre-commercial heat pump prototype.

Four combinations of two different compressor pulleys and two different fan-blade-motor-sets were tested. The pulley ratios tested (engine: compressor speed) are 1:1 and 1:1.125. The blade-motor sets ratings are $1 / 3$ and $1 / 4$ horsepower. The higher pulley ratio resulted in higher refrigerant flow rate, in turn more capacity, but required higher torque, in turn more flow. The higher horse power fan-blade pushed more air across the outdoor coil, lowering the discharge pressure and increasing capacity/reducing fuel 
consumption, but consumed more electric power. Each of the four combinations were tested at two different outdoor temperatures, 95 and $125^{\circ} \mathrm{F}$, to assess the impact of the pulley ratio and fan capacity on the COP and operability limit. Based on the results, decision was made to proceed with the 1:1.125 pulley and the $1 / 3 \mathrm{HP}$ fan.

Table 9 Performance testing results of pre-commercial heat pump prototype.

\begin{tabular}{|c|c|c|c|c|}
\hline Eng RPM & Ambient Temp & Mode & Capacity & Gas COP \\
\hline 1200 & 82 & Cooling & 26,029 & 1.72 \\
\hline 1800 & 82 & Cooling & 32,379 & 1.39 \\
\hline 2400 & 82 & Cooling & 37,333 & 1.18 \\
\hline 2800 & 82 & Cooling & 46,426 & 1.19 \\
\hline 3400 & 82 & Cooling & 54,202 & 1.09 \\
\hline 1200 & 95 & Cooling & 18,821 & 1.22 \\
\hline 1800 & 95 & Cooling & 31,902 & 1.32 \\
\hline 2800 & 95 & Cooling & 49,086 & 1.17 \\
\hline 1200 & 105 & Cooling & 8,736 & 0.55 \\
\hline 1800 & 105 & Cooling & 22,603 & 0.89 \\
\hline 2800 & 105 & Cooling & 38,455 & 0.85 \\
\hline 1200 & 115 & Cooling & 13,531 & 0.80 \\
\hline 1800 & 115 & Cooling & 22,782 & 0.83 \\
\hline 2800 & 115 & Cooling & 36,200 & 0.78 \\
\hline 1200 & 125 & Cooling & 9,868 & 0.53 \\
\hline 1800 & 125 & Cooling & 19,972 & 0.66 \\
\hline 2400 & 125 & Cooling & 25,071 & 0.77 \\
\hline 2800 & 125 & Cooling & 24,589 & 0.75 \\
\hline 3400 & 125 & Cooling & 24,487 & 0.75 \\
\hline 1200 & 10 & Heating & 7,249 & 0.47 \\
\hline 1800 & 10 & Heating & 13,267 & 0.55 \\
\hline 2400 & 10 & Heating & 26,320 & 0.81 \\
\hline 2800 & 10 & Heating & 29,862 & 0.75 \\
\hline 3400 & 10 & Heating & 39,661 & 0.79 \\
\hline 1200 & 17 & Heating & 7,158 & 0.46 \\
\hline 1800 & 17 & Heating & 17,182 & 0.71 \\
\hline 2400 & 17 & Heating & 26,845 & 0.82 \\
\hline 2800 & 17 & Heating & 33,897 & 0.84 \\
\hline 3400 & 17 & Heating & 44,736 & 0.88 \\
\hline 1200 & 35 & Heating & 17,564 & 1.14 \\
\hline 1800 & 35 & Heating & 29,955 & 1.25 \\
\hline 1200 & 47 & Heating & 22,839 & 1.49 \\
\hline
\end{tabular}




\begin{tabular}{|c|c|l|c|c|}
\hline Eng RPM & Ambient Temp & Mode & Capacity & Gas COP \\
\hline 1800 & 47 & Heating & 33,074 & 1.37 \\
\hline 1200 & 75 & Heating & 46,246 & 2.89 \\
\hline 1800 & 75 & Heating & 62,125 & 2.49 \\
\hline
\end{tabular}

In preparation for commercialization, a design review was conducted. Components were re-arranged to reduce foot print and improve serviceability (Figure 21.) The new design also improves the manufacturability of the unit and reduces the cost of assembly. This was accomplished through significantly reducing the number of joints (screws were reduced by more than half.)

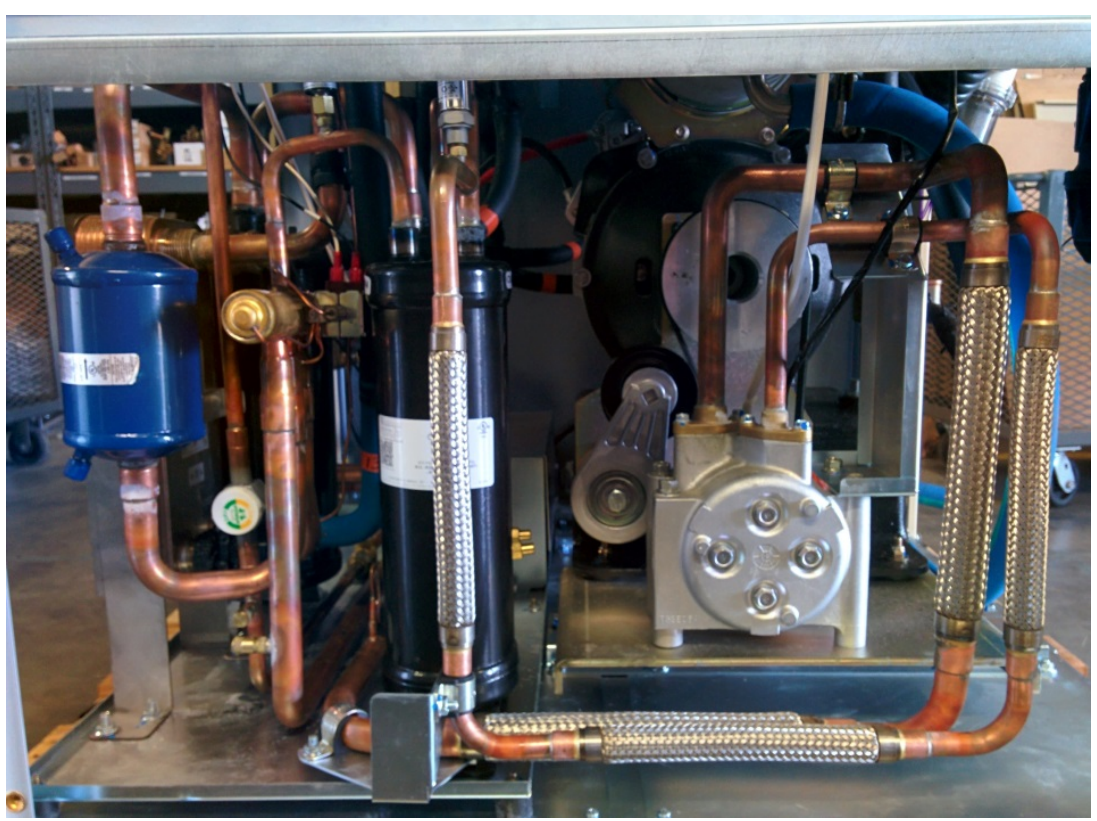

Figure 21 Components were rearranged to reduce footprint. 


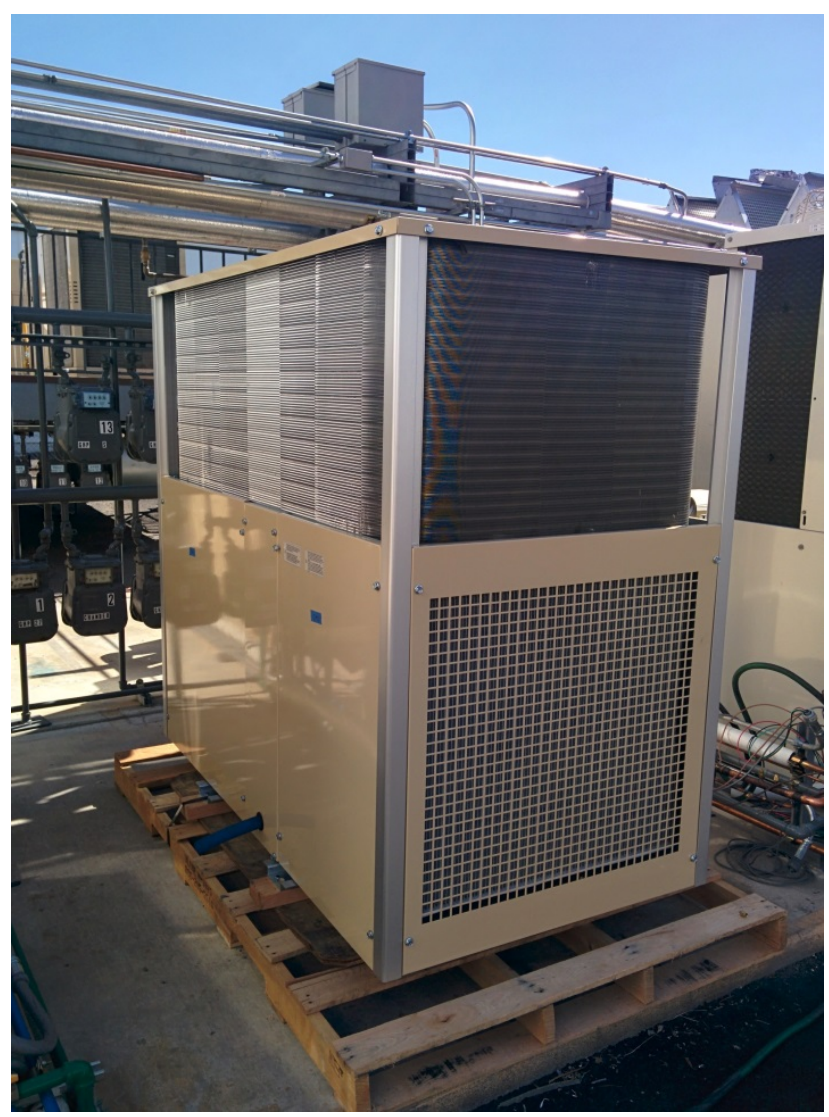

Figure 22 Final design of the heat pump.

\section{COMMERCIALIZATION POSSIBILITIES}

Market penetration of the residential FFMHP requires lowering the initial cost of the unit. It also requires marketing and servicing infrastructure. SWG is discussing a collaboration project with Gas Technology Institute (GTI) Utilization Technology Development (UTD) group about the possibility of introducing the unit into the market. If successful, GTI UTD will conduct a market analysis to assess the commercial viability of the heat pump. SWG is also promoting the search of investors through GTI UTD. Investors are needed to provide the capital needed to manufacture the heat pump in high volume. The initial cost will decrease if the scale of production increases.

Since the engine is the highest-cost component, a search was conducted for a less expensive option. Isaac Mahderekal, IntelliChoice Energy, has found an engine (manufactured in China) that is about half the cost of the current engine. The new engine option is currently in stress testing to verify its reliability for the FFMHP application. 


\section{PLANS FOR FUTURE COLLABORATION}

As of the time of writing this report, there were no specific plans in place for further collaboration on this project. However, the engine is one potential area for further collaboration. Lowering the cost of the engine and enhancing its reliability would greatly improve the marketability of the FFMHP system.

\section{CONCLUSIONS}

A residential scale version of a gas engine driven heat pump (the FFMHP) has been developed and tested. The design of the heat pump has evolved through several iterations. The final design was optimized to have the smallest possible footprint, the lowest possible electric consumption, and the best possible efficiency. The product is ready for market. SWG estimates that a unit cost target should be $\$ 8000$ for the gas heat pump to penetrate the market. The current cost of production is higher than the target.

\section{REFERENCES}

ANSI/AHRI Standard 210/240-2008, "Performance Rating of Unitary Air Conditioning \& AirSource Heat Pump Equipment".

\section{ACKNOWLEDGEMENTS}

The authors thank Mr. Antonio Bouza of the DOE Building Technology Office (DOE/BTO) for supporting ORNL's work on this CRADA project under Contract No. DE-AC05-00OR22725 with UTBattelle, LLC. We would also like to acknowledge the great supports from Mr. Isaac Mahderekal at IntelliChoice Energy, Mr. Randall Wetherington, Neal Durfee and Randall Linkous at ORNL. 